\title{
Teaching crime fiction and the African American literary canon
}

Book or Report Section

Accepted Version

King, N. (2016) Teaching crime fiction and the African American literary canon. In: Shaw, K. (ed.) Teaching 21st Century Genres. Teaching the New English. Palgrave Macmillan, London, pp. 47-65. ISBN 9781137553898 doi: https://doi.org/10.1057/978-1-137-55391-1 Available at http://centaur.reading.ac.uk/67208/

It is advisable to refer to the publisher's version if you intend to cite from the work. See Guidance on citing.

To link to this article DOI: http://dx.doi.org/10.1057/978-1-137-55391-1

Publisher: Palgrave Macmillan

All outputs in CentAUR are protected by Intellectual Property Rights law, including copyright law. Copyright and IPR is retained by the creators or other copyright holders. Terms and conditions for use of this material are defined in the End User Agreement. 


\section{www.reading.ac.uk/centaur}

\section{CentAUR}

Central Archive at the University of Reading

Reading's research outputs online 


\section{Dr Nicole King, University of Reading \\ The Crime Fiction of Attica Locke and the African American Literary Canon}

Teaching African American literature, whether it is designated as 'literary' or 'popular,' is political and carries with it a political resonance. According to some calculations detective stories are the most widely read literary genre in the United States but the fact that African American writers have been writing in this genre since the early twentieth century is likely to be less well known. ${ }^{1}$ Rudolph Fisher's The Conjure Man Dies: A Mystery of Dark Harlem (1932) is understood as an important precursor to the mid and late twentieth-century crime fiction of Chester Himes and Walter Mosley. Earlier still, in 1901, Pauline E. Hopkins used the Colored American magazine to serialize her novel Hagar's Daughter which features the first black female detective in fiction. ${ }^{2}$ Both Fisher and Hopkins are regularly anthologised and recognised by scholars as important contributors to the canon of African American literature, but neither Hagar's Daughter nor The Conjure Man Dies are the texts chosen by editors of anthologies. ${ }^{3}$ Similarly, despite the common practice in English literature departments to teach popular and genre fiction such as romance, science or crime fiction, an informal survey of university courses reveals that the appearance of crime fiction modules which focus exclusively on African American writers are uncommon. It appears far more likely to encounter African American crime fiction on broadly defined modules where 'genre' or 'crime' is the main focus. ${ }^{4}$ Perhaps this is due to an implicit respect for the different attributes and histories of crime fiction (and other popular genres) and African American literary fiction. But beyond such impressions is there a robust pedagogical reason not to devise an African American crime fiction module? As a specialist in African 
American literature would I hesitate to teach such a module ${ }^{5}$ Until recently, my answer was yes, I would hesitate and I have hesitated, moreover, the absence of such modules suggest that others have hesitated too.

To understand why African American literature modules tend not to teach popular-specifically crime-and literary fiction in equal measure requires an examination of how African American literature is defined and viewed in addition to a focus on the pedagogical possibilities offered by forthrightly addressing concepts of the popular and the literary within an African American cultural context. This essay makes a three-pronged argument: First, I examine how attitudes towards teaching as well as the contexts in which we teach have a profound effect on what we choose to teach. Second, if a general pedagogical aim in teaching African American literature can be summarized as a project that acknowledges and interrogates the literature's distinctive, shared themes and tropes $^{6}$, then African American crime fiction can be understood as an under-utilised component of such a pedagogical project. Third, I use a reading of the crime fiction novel, The Cutting Season (2013) by Attica Locke, as a case study to show how particular texts blur the boundaries between literary and popular and how they might be successfully used to frame and populate a module devoted to African American literature. ${ }^{7}$ In addition, The Cutting Season is a text where an ethos of teaching and learning inform the plot, setting and characterisations. I conclude that a combination of popular and literary, or canonical, texts can provide new ways of teaching African American literature to university students. Importantly, it is a method that includes students in a conversation about the continued, if sometimes implicit, judgements about literary 
value which in turn inform which texts are placed on reading lists and how they are taught.

\section{Contexts and consequences}

Although some argue that the distinctions made between high-brow and low-brow, serious and pulp, popular and literary fiction are spurious, such distinctions have a long a history and persist. ${ }^{8}$ New Criticism teaches a particular valuation of literature and keeps in place 'a rigid division between high and low, or elite and mass culture, an emphasis on invention over convention, and a distinction between literary and commercial forms of literature. ${ }^{\prime 9}$ Within the classroom (as opposed to a more capacious anthology) a tendency to exclude the so-called low is sometimes as true for African American literature as any other literature. On a personal level, although my research and teaching has been predominantly shaped by feminist, postcolonial and poststructuralist discourses, I have not automatically escaped some of the influences of New Criticism when tasked with curriculum design. And what I observed in my teaching practice is mirrored on the larger stage of US and UK academia.

One of the implicit reasons for maintaining boundaries between literary and popular African American fiction in my teaching is linked to the situation of African American literary instruction in the academy: somehow, there often does not seem to be space to accommodate both the popular and the literary within the curriculum of a single module. In higher education contexts such as that of the UK, the opportunity to study African American literature as an undergraduate are limited by programmatic specifications such as the typical three-year degree length and the necessity to take many required modules. At my current institution, first and 
second-year students encounter African American literature in the form of one or two texts major texts, (e.g. Invisible Man or Erasure) studied on deliberately broad modules such as American Literature, Introduction to Poetry or Contemporary Fiction. Students have the chance to take my African American Literature seminar in their final year but without a previous module's worth of foundational, African American canonical works that their American counterparts, for instance, would have had access to in their first, second or third year. ${ }^{10}$ Previously, I reasoned that given the very limited opportunities to teach African American literature in a threeyear degree, there is a pedagogical imperative to concentrate on canonical texts and sacrifice popular or genre fiction such as crime fiction when teaching African American literature; I saw the two categories of literature as distinct and with different pedigrees. But there were additional layers of reasoning that I was less inclined to acknowledge and which expose an often obscured vulnerability that comes with teaching and speak to more personal aspects of the act of teaching than academics are commonly asked to articulate.

Most prominent among such vulnerabilities is the notion of how perceived literary value is linked to perceived intellectual standing. If colleagues are teaching canonical texts in a jointly taught module, as is common in the UK, then I feel compelled to do the same. My default position would be to always choose an author like Nobel prize-winning Toni Morrison over the hugely popular Terry McMillan for either an American literature or an African American literature survey module. In contrast, when teaching at three quite different universities in the United States (the University of Pennsylvania, the University of Maryland and the University of California, San Diego) colleagues and I had opportunities to teach modules devoted 
solely to African American Satire, Women's Literature, Neo-slave Narratives, Poetry, and to historical periods such as the Harlem Renaissance, the Cold War and the Black Arts Movement. Within the latter three examples in particular, it was not uncommon for us to incorporate the study of popular and visual culture, as well as popular fiction as might be found in magazines. Thus, in addition to perceptions of academic standing there are structural differences and limitations to how we might teach African American literature in the UK or elsewhere where curricular flexibility might be, or simply feel, restricted. As these examples show, the spaces and contexts in which we teach is intimately bound to what we teach and the approaches to teaching that we adopt.

How specialists, like myself, conceive and teach the African American literary canon is further connected to how African American literature is positioned within the broader American literary canon and how academics of all ethnicities and subject positions who teach non-white and/or non-canonical literatures are situated within the institutions in which we work. In the UK, perhaps understandably, African American literature is a minoritized literature, subordinated to American literature in which 'American' stands in for literature penned by ethnically white men and women which in turn stands in for canonical, in the 'New Criticism' sense of the canon. To teach the breadth and diversity of African American literature then, to accurately signal its cultural reach and significance beyond higher education, the literary establishment and the milieu of Anglo-American culture, requires the installation of a different pedagogical framework. Such a framework could use African American literature itself to delegitimise boundaries between high and low culture, between canonical and popular literature, and thereby destabilise 
foundations that might be sexist, racist, and elitist. ${ }^{11}$ Crime fiction is a component of African American literature that can achieve this.

The student-led 'Why is my Curriculum White' campaign attests to how the feeling amongst some UK students that a monocultural curriculum fails to deliver a high-quality education is made more visible than ever through social media. ${ }^{12}$ This popular movement highlights the political impact of the curriculum choices lecturers make. African American crime fiction, although it is not always about social justice, does frequently use realism, plot and genre conventions to expose and comment upon a history of subjugation and unequal treatment of black people (and other minority communities) in the US, the legacy of slavery and state-sanctioned violence against African American citizens. As Lee Horsley notes, '[c]rime fiction has qualities that make it well-suited to the task of critique and protest ... its protagonists are marginalised, outsiders forced into awareness of the failings of established power structures...'13 It is an added pedagogical bonus that African American literary fiction and crime fiction have overlapping imperatives. The familiarity of a popular genre such as crime fiction can prove to be a useful pairing with African American literary fiction for students who have little knowledge of the latter. While I will turn to a full discussion of The Cutting Season in the final section of this essay, it is worth noting here that Locke's characters Donovan Isaacs and Caran Gray, as well as the ancestral figure of Jason, are each marginalised and become aware, in very different ways, of the failings of established power structures and each offer 'oppositional critiques' of these structures. ${ }^{14}$ The fact that some crime fiction texts can be selected which draw upon the shared themes and tropes of the African American literary tradition contravenes my previous assumptions and make it both a logical and a canny choice 
on a syllabus where a lecturer is trying to provide a broad view of African American fiction.

Despite such parallels and affinities between crime fiction and African American literary fiction, the argument against bringing any popular fiction in the literary classroom is familiar if not necessarily robust. Helen Carr reports the twinned attitude that crime fiction lacks intellectual currency and depth and is conservative rather than subversive, indeed genre fiction is often perceived as a 'low-level, formulaic production'. ${ }^{15}$ Yet, speaking broadly of both popular culture and specifically of popular fiction, Herman Beavers reminds us, 'the narrative variety of popular culture produces a set of sophisticated reading strategies that belie the charge that popular fiction is characterized by a mindless adherence to plot and fantasy'. ${ }^{16}$ Further, given the relatively small number of African American texts that have been canonized 'it is a mistake to uncouple popular fiction from literary fiction or belles-lettres'.17 I would add to this that the notion of crime fiction being conservative rather than subversive shifts considerably when we are discussing specific examples of African American crime fiction. It might be conservative in terms of following crime fiction conventions and reproducing familiar narrative arcs, but all genres do this. One way in which African American crime fiction can be understood as unconventional is in terms of giving voice to protagonists, e.g. marginalised people of colour, more likely to be silenced in other works of crime fiction and or absent altogether from literary fiction written by Anglo-American authors. Another way is in terms of narrative innovation. Citing Ishmael Reed and Clarence Major, Stephen F. Soitos writes, 'both authors revise the traditional classical and hardboiled formulas...' and they transform the formulas previously 
adhered to by other African American authors of crime fiction through

'experimentation with the double-conscious detective trope.' ${ }^{18}$

Ultimately, my sense that African American popular and literary fiction both 'do' different things and are seen to do different things is not anomalous, however, and is indicative of what Dietzel calls a web of 'exclusionary' reading practices derived from New Criticism. Since the ethos of black crime fiction has been said to have some of the same critical intentions as black literary fiction - e.g. to critique racism, to focus on racial uplift, to 'affirm' blackness ${ }^{19}$ while it also demonstrates a double-voiced, signifying text, ${ }^{20}$ a perceived division between high and low culture, or literary and commercial fiction, among African Americanists is only part of the issue and points to a wider cultural phenomenon that ifiltrates the spaces in which we teach and in which students learn. An important intervention then is to call attention to these permeable boundaries even as we choose to teach texts which skilfully transgress them altogether. ${ }^{21}$ Conversely, as Wells asserts, where crime fiction has been understood as 'a notoriously conservative genre', crime writers who critically engage with racialization and introduce complex racialized characters to their narratives, work 'to disturb the genre' and break down its boundaries. ${ }^{22}$ Crime fiction by African American authors (and Black British authors as Wells demonstrates) works in conversation with literary fiction as it goes about the work of contestation and questioning of racial and cultural monoliths. Whilst there is a dearth of university modules focused exclusively on African American crime fiction, it is important to note that although no specific statistics are available, African American crime fiction is taught in UK universities. Dr Sam Thomas at the University of Durham offers an MA module in US Crime Fiction, which includes texts by Attica 
Locke. ${ }^{23}$ Dr Will Norman at the University of Kent teaches an American Crime Fiction module to undergraduate students in their final year. He has been teaching this module for six years and it includes texts by both Chester Himes and Attica Locke. ${ }^{24}$ Dr Lee Horsley pioneered undergraduate and postgraduate crime fiction modules at the University of Lancaster in the first part of this century, and, like Helen Oakley at the Open University, is particularly attentive to the position of and narratives by black and other non-white writers in the context of research and teaching about crime fiction.

\section{The literariness of African American crime fiction}

There is a wealth of African American crime fiction to choose from to trouble the boundaries between literary and popular fiction including Walter Mosley's Easy Rawlings series, Barbara Neely's Blanche on the Lam series, and Chester Himes's Coffin Ed Johnson and Gravedigger Jones series. Within this milieu The Cutting Season functions as an exemplar text: although it is written in the crime fiction genre and is sold and marketed as crime fiction, like its predecessors listed above, it actively dissolves the boundary between literary and crime fiction by balancing crime fiction conventions and African American literary tropes, the so-called high and the low. As such it reminds us of the paradox of an African American literary canon which has always included fiction that began life as popular and became literary afterwards such as Native Son (1941) as well as texts that are firmly within the canon but which have never been bestsellers, such as Ralph Ellison's Invisible Man (1952) and Toni Morrison's Beloved (1987). ${ }^{25}$ Such texts amply prove that aspects of both literary and popular African American fiction are concerned with history, racial identity, double-voiced texts and signifying. 
Dietzel also calls attention to breadth and depth of African American

literature that by virtue of being popular and produced for a mass market, is highly significant to the African American reading public and yet all too easily ignored by literary scholars. Thus there are cultural, political and historical arguments for reading popular African American literature alongside texts that have entered into the canon. Dietzel, like Carr, Beavers and others, in their discussions of popular African American fiction and crime fiction, argues forcefully against the separation of the popular and the literary that continues in the twenty-first century. She calls attention not just to the rigid divisions of literary categories but also highlights the gap which exists between how literature is experienced and evaluated by the general public and how it is experienced and evaluated by many university lecturers:

In the fields of literary criticism and the teaching of African American literature, for example, scholars and critics alike have restricted their efforts to reviewing, promoting, and canonizing only those texts that fit the prevailing aesthetic and literary standards. . Applying these standards to African American literary texts (and indeed all literary traditions) has pushed much of its literary production out of the classroom, off the bookshelves, and into the dustbin of literary history. ${ }^{26}$

Dietzel makes a strong case for thinking carefully about what we choose not to teach. By excluding the popular by design or by default we impoverish the literary diet of the very people keen to expand and diversify their intake. I would add that when we consider that there is more to lose than to gain by keeping the popular and literary separate, the inclusion of the popular automatically becomes part of the familiar enterprise of recovery and restitution that much of the literary fiction of African American literature has benefited from. By teaching authors who have established themselves as popular by virtue of book sales, such as Terry McMillan 
(Waiting to Exhale) or by virtue of writing within a popular genre such as crime fiction, such as Mat Johnson (Hunting in Harlem), as part of the multi-faceted world of fiction by and about black Americans we are doing work that expands the breadth and depth of African American fiction. It is work in a similar mode to that of the Schomburg Library of Nineteenth-Century Black Women Writers series which brought twenty plus works to scholarly prominence in the 1990s. It is work that is also similar to the scholarship of Jean Fagin Yellin which rescued Incidents in the Life of a Slave Girl (1861) from being considered a 'fabrication' and confirmed it for many as 'the most important book in the antebellum era by an Afro-American woman. ${ }^{27}$ The point of including the likes of Locke, McMillan, and Johnson on an African American literature syllabus is to initiate a discussion about what questions their inclusion can raise about the usefulness of qualitative divisions between categories of literature when texts can be found in all categories which deploy standard tropes of African American literary and cultural expression. I have become convinced that the university classroom is a place where it is problematic to make a pedagogical justification for separating out the study of different forms of African American literary expression based on oppositional notions of popularity and literary value. When opportunities to study African American literature are restricted to one module, a broad spectrum can be as useful to the student as a single author study.

\section{Crossing the Threshold: what and how The Cutting Season teaches}

By situating the contingent nature of identity in both the present and the past, Locke's contemporary, popular text of genre fiction enables readers to acquire a threshold concept of African American literature: the fallacy of race as a natural, biological marker of difference between human beings. ${ }^{28}$ The Cutting Season's 
presentation of markers of racialisation and identity as neither stable nor inherent are two key messages of canonical African American literature such as The Narrative of The Life of Frederick Douglass, Their Eyes Were Watching God, Passing, Invisible Man, A Raisin in the Sun and others. These are texts that themselves teach the reader to examine the complex interplay between representations of gender, history, location, class and sexuality in the portraits of black Americans and American culture(s). The Cutting Season uses a wide variety of plot and character devices to present itself as a text that teaches, and as a text that values the types of questions (and questioners) found on the margins of established norms and ways of knowing. As Meyer and Land elaborate, threshold concepts that allow students to make transformative leaps in their understanding of a subject or discipline can be, and often are, simultaneously troublesome. ${ }^{29}$ The fallacy of race can be a counterintuitive concept for students to grasp and requires an undoing of understanding 'race' as biology and moving towards the notion of racialisation as cultural, social, and political. I argue that popular, commercial, genre fiction is no more or less able than literary fiction to present such pedagogical projects, though it may have the advantage of accessibility. No matter what type of fiction students are reading, I have found it impossible to rely on their tacit knowledge of African American literary expression or tacit understandings of race as a construct. Rather, in guiding them over this threshold of their understanding, how words are used and in what context are the key to helping students access new angles from which to think about the idea of 'race.' As Meyer and Land state, with well-chosen examples for our students '...the inert, superficial mimetic use of language of a threshold concept becomes enlivened'. ${ }^{30}$ Such examples are frequent in The Cutting Season, and the 
troublesome concepts are potentially less so as they are delivered within the familiar contexts of the crime fiction genre, that borrows knowingly from conventions of African American literary fiction. The Cutting Season generously provides a layered presentation of the malleability of racial thinking and racial identities.

For the student of either African American fiction or crime fiction the setting of The Cutting Season will likely be immediately evocative and disconcerting. While the images of slavery and slave plantations will no doubt be familiar, the fact that in the twenty-first century there are restored, operational plantations, albeit with migrant rather than slave labour, which serve both a business and cultural heritage function, may feel jarring to the reader who presumed that the social and cultural relations occasioned by chattel slavery were safely confined to a two-dimensional past. The Cutting Season is set on the restored grounds of a Louisiana sugar cane plantation home, Belle Vie. The protagonist, Caran Gray, grew up there and returns, at age 37 , as its general manager when she relocates with her 9-year old daughter from New Orleans in the aftermath of 2005's Hurricane Katrina; we meet her in 2009. Belle Vie can be rented out for weddings, offers tours to school groups and other members of the public curious about 'the old South'. A feature of Belle Vie (like many actual tourist attractions in the American South) is its live re-enactments centred on a romanticised theatrical production called 'The Olden Days of Belle Vie' that portrays life on the plantation before, during and just after the Civil War. ${ }^{31}$ The murder that drives the narrative of The Cutting Season is that of a migrant worker from the adjacent, active, 500-acre sugar cane plantation. This active plantation is one of the text's many complex representations of the 'new' South. ${ }^{32}$ The body of the murdered woman, Inés Avalo, is found by Caran Gray on Belle Vie's grounds, and 
Gray goes on to assist, confound and ultimately solve the police investigation of the murder plus another one that happened a century and a half earlier and which involved her great, great, great grandfather, Jason, a former Belle Vie slave. How history is understood and which histories are known is a central theme of the text and one which links it to the work of archival literary scholarship mentioned in the previous section. In an interview Locke states that in The Cutting Season she was particularly concerned with the position occupied by history in the contemporary moment, how 'the narrative of American history gets - who gets to own it, how does it get presented, how do we consume that history?.' ${ }^{\prime 3}$ She mentions in the same interview that she sees fiction's 'power as an instrument of social justice almost unparalleled'; she does not make a distinction between the power of popular and literary fiction. ${ }^{34}$

The Cutting Season overtly challenges the boundaries between so called popular and literary fiction by braiding together key attributes of crime fiction and African American literature. Deborah Madsen writes that African American literature is centrally concerned with issues of 'memory and memorialisation, of history and historical reconstruction, of literature and social justice, of language and identity.' ${ }^{35}$ The Cutting Season reflects this emphasis with its juxtaposition of the contemporary and the historical, the forward driving narrative of solving the crime with the backwards movement through history and family relations. In these ways The Cutting Season sits quite comfortably alongside texts like Native Son, The Street, and If He Hollers Let Him Go, which are now part of the African American literary canon and which, for example, feature murderous or wrongly accused protagonists and deliver commentaries on racialized social injustice. 
The Cutting Season also announces its affinity with the African American canon and its concerns through intertextuality. It names Gone with the Wind and Uncle Tom's Cabin, and at other times signifies upon Toni Morrison's Song of Solomon (Chapter 7) and Ralph Ellison's Invisible Man ( $\mathrm{p} 338$ ). The Cutting Season is crime fiction and yet participates in the same conversation as African American literary fiction, using similar tropes of invisibility, ancestor texts, and the talking book in concert with a narrative that uses history to help make sense of the present. The text significantly blurs the boundaries between popular and literary fiction in its simultaneous adherence to certain conventions of crime fiction such as the alienated outsider figure (Caran Gray and Donovan Isaacs both fill this role) and to the formal and stylistic moves of canonical African American authors, known as double-voiced or signifying. As such, The Cutting Season easily allows students and lecturers to foreground questions about the categorical and qualitative divisions of literature. The Cutting Season suggests the need to account for the popular in literary fiction and the literary in popular fiction while also providing a context in which students can learn the value of critically engaged reading no matter what the context or genre of text they encounter.

In addition to the 'whodunit' narrative strand in The Cutting Season, part of the tension of the novel revolves around how and why of the theatre piece, 'The Olden Days of Belle Vie', topples from its pedestal as the canonical narrative of the plantation's history. 'The Olden Days of Belle Vie' is a key paratext and is the literary fiction convention that Locke uses to highlight the performativity of racial identities as contingent on and produced within a very particular historical narrative of the nation. As a 'doubled' text the play script is highlighted by Locke as an 
unstable and variable one. Donovan Isaacs, a member of the 'Olden Days' cast who plays FIELD SLAVE \#1 eventually gets fed up with the banality of his role and of the whole play. One of Caran Gray's most unreliable workers and the prime suspect for the murder, he also happens to be re-writing the racist, stereotype-laden play script in order to tell a different story, in order to unearth a buried history. Isaacs aims to re-write the way history is consumed on the planation by tourists and school groups alike because he feels that the script needs to change, not least because it the $21^{\text {st }}$ century. The contemporary time frame of the text, 2009, is particularly relevant in this respect: it is one year into the first term of Barack Obama's presidency and the possibility of scripting a different American narrative, one which rejects static concepts of race and identity, is still quite fresh.

Although Caren Gray is the main protagonist and helps solve the present-day murder of Avalo, Isaacs' social position in the text is of inverse importance to the teacherly role he occupies and the significance of his work to revealing the hidden history of Jason. He is initially presented as a disaffected youth just getting by at the local community college. He is 'off-stage' and he occupies the margins of the text and his work is itself hidden and in the shadows for much of The Cutting Season. His marginality in the text is symbolic of rebellious enslaved men and women who plotted in secret to overturn slavery and it is also symbolic of many types of authors who wrote (and write) against the odds of their condition as marginal to dominant social, cultural and economic structures.

The reader eventually learns that Isaacs not only persuades the other cast members to learn new lines, he convinces them to create something altogether new: he has them help him to make a film that leaves behind the hackneyed southern 
belles and white patriarchs, the stereotypes of mammies and field slaves contained within the characterisations of 'Olden Days'. Isaacs's film, 'Raising Cane: A New Sheriff in Town,' focuses on a brief period during the Reconstruction Era when exslaves and other black people held some political power and the Parish of Belle Vie, where Isaacs and Gray and the others still live and work, had a black sheriff. The film subverts and re-writes the publically consumed view of the Old South presented by 'The Olden Days of Belle Vie' much the same way African American literature can be seen to subvert and rewrite the canon of American fiction and indeed much the same way that crime fiction written from a multicultural perspective has been shown to subvert the hard-boiled formula. ${ }^{36}$ Drawing on Maureen Reddy's work on detective fiction featuring black women, it is evident that there are both reverse and counter discourses at work in The Cutting Season. Writing about black women detective series, Reddy notes that they all 'question the conventional crime plot's movement from disorder to order and injustice to justice, and collectively redraw the borders of the crime fiction genre' ${ }^{37}$ The film script nested within the narrative of the crime which structures The Cutting Season conforms to such a model where untidy narratives, disorder and injustice are deployed to expose and teach a different version, and ultimately a different understanding of both nineteenth century history, and the 2009 world of the protagonists. In the context of The Cutting Season as a text that teaches, it is incredibly significant that Isaacs uses the plantation archives, housed in the plantation library, to write, stage and create 'Raising Cane' and that the film begins life as a project for one of his classes. His labour is the key to solving the mystery of Jason's disappearance, the theft of his property and his murder but this historical recovery is perhaps less significant than 
the feat that Locke pulls off in forcing her reader, through the perspective of Caran Gray, to see Donovan Isaacs as someone to learn from. Locke asserts, 'we need to balance stories about the past with stories that deal deeply with racial issues in the present' and for the characters in The Cutting Season one way this is realised is through the acknowledgement of black identities as shifting, diverse and subject to intra-racial conflict in addition to the persistence of racism and racial terror.

Locke weaves her subversive narratives together with finesse - the murders of ancestor Jason and migrant worker Inés Avalo are solved but order is not restored in part because the complex history of Belle Vie plantation as well as American slavery were founded on violence, disorder and mayhem and so there is no foundational order or stability to recover or return to. The traditional neatness of the crime novel is treated with scepticism by Locke and offers space for an ironic commentary on the crimes of American and Europe against black people. But she also moulds the crime fiction genre to her own purposes, which Soitos asserts is common to African American writers of crime fiction. ${ }^{38}$ By the conclusion of The Cutting Season the plantation of Belle Vie, its history and present $21^{\text {st }}$ century meanings are neither recuperated as a nostalgic haven of white superiority or for a putatively liberating sense of black empowerment. Rather, Locke emphatically questions idealised and essentialising modes of cultural identity. This questioning is emblematic of The Cutting Season's teacherly tropes. It repeatedly represents formal and informal education and details how certain versions of history are reiterated and reproduced (e.g. 'The Olden Days of Belle Vie') whilst others lay buried or on the margins. The reader is invited to view the significance of Inés Avalo's body being found literally on the margin, on the border between the active 
and the inactive plantations for how we understand contemporary labour relations as well as cultural conflicts and allegiances. Locke's text is crowded with everything we expect from the genre: false leads, twists and turns, a protagonist with her own share of flaws. Locke's text makes it difficult to read American history as one of forward progress or one where racial, ethnic, and social divisions or political power was ever absolute for any particular group. It is a crime fiction novel that patiently prompts the reader to cross various thresholds of understanding and to revise any notion they may have brought to the text about singular identities or singular truths.

If Donovan Isaacs can be understood as a teacher forged in the clamour of Obama gaining the White House, then Morgan, Caran Gray's daughter, must also be examined as the text's prototypical student of the contemporary moment. She is central to the plot of the novel --she discovers key clues-- as well as to the play within the novel. She literally bears witness to key events as well as bearing witness more symbolically to the changing script of Americanness as it unfolds around her. The rehearsals for the play take place in an old plantation building that functioned as a school house during the Reconstruction era, and she learns from the play script as well as from the adults around her about the suddenness of violence and the slipperiness of truth. Like Lutie Johnson in The Street, like Ellison's protagonist in Invisible Man, like Bigger Thomas in Native Son, Morgan is taught about and influenced by a different way of reading racial identity and that there are always multiple ways to tell a particular story. These are overlapping themes in African American literary texts as well as in African American crime fiction.

Locke opens a space for unknowability, open questions, and diverse perspectives on truth and history. As such she is following in the footsteps of other 
African American crime writers by subverting the conventions of the genre much the way Douglass subverted the adventure narrative in Narrative of the Life of Frederick Douglass (1845) and much the same way Jacobs subverted the romance in Incidents in the Life of A Slave Girl. Indeed Locke reminds us of how much commonality there is between what is categorised as popular versus literary African American texts. Her reader knows there will be a resolution not just to a problem, but to a crime, indeed that is a generic agreement the author commits to. But Locke, like other authors of crime fiction who are not only concerned with adhering to reader expectations of generic conventions, complicates the reader's expected pleasure by presenting competing narratives which cumulatively destabilize 'truth' in order to solve a crime, revealing truth to be contingent like knowledge and identity.

\section{Conclusion}

The epistemological frameworks that are opened up through Locke's texts are multiple. The texts suggests new ways of framing knowledge, by critiquing how it is been framed in the past and provides provocative representations for how learning occurs. In this way using The Cutting Season to frame a module that attends to the teaching of literary and popular African American fiction together is doubly profitable: it allows students access to questions about how their own teaching and learning is framed and how canons frame our knowledge of particular literary traditions. The Cutting Season simultaneously works in conversation with a variety of texts, popular and literary, to impart some of the key features of African American writing, including social protest, signifying, memorialisation and the troubling of genre conventions. Furthermore, as a crime fiction novel The Cutting Season suggests how a more creative and questioning pedagogical practice is possible within 
the teaching of African American fiction and, in my own practice at least, forced questions about the categorical and qualitative division of literature to the surface. In this essay I have argued for a renewed interrogation of canonicity when we teach African American literature for the very reason that talking about the canon offers an opportunity for students to both understand and question how they are taught and what they are taught. In this way the development of student expertise is achieved through close reading, theorisation of identity as well as reflective learning practices. I have shown how a popular literary genre such as crime fiction, with its attention to form and freedom to 'play' and be entertaining, can be an effective means through which readers might understand and map the contingencies and contradictions of the prose, poetry and drama that is taught and presented as African American literature. 


\section{Notes}

Thank you to Dr Leila Kamali and Dr Tita Chico for their very helpful comments and suggestions.

${ }^{1}$ Suzanne B. Dietzel, 'The African American Novel and Popular Culture' in, ed. Maryemma Graham The Cambridge Companion to the African American Novel (Cambridge University Press, 2006) 159.

2 Ibid., 158.

${ }^{3}$ See, for example, Henry Louis Gates Jr and Nellie Y. McKay, editors The Norton Anthology of African American Literature Second Edition (W.W. Norton \& Co, 1997, 2004) xiii.

${ }^{4}$ This is true of the University of Kent, Lancaster and Durham, for instance, where their popular crime fiction modules focus on the genre and include contributions by African American authors.

${ }^{5}$ I have taught and written about Walter Mosley's Devil in A Blue Dress, see Nicole King (2002) "You think like you white": Questioning Race and Racial Community through the Lens of Middle Class Desire(s).' Novel: A Forum on Fiction, Spring/Summer, 211-230. I have also taught Hunting in Harlem by Mat Johnson and The Cutting Season.

${ }^{6}$ Henry Louis Gates 'The Master's Pieces' in Loose Canons (Oxford: Oxford University Press, 1992) 39.

${ }^{7}$ Locke is also the author of two other crime fiction novels, Black Water Rising (2009) and Pleasantville (2015).

${ }^{8}$ Peter Swirski, From Lowbrow to Nobrow (Montreal: McGill-Queen's University Press, 2005), 5.

${ }^{9}$ Dietzel, 'The African American Novel', 156.

${ }^{10}$ The University of Pennsylvania demonstrates a typical pattern in U.S. universities where broad modules such as 'Introduction to Black American Writing' are open to non-majors and honours modules such as 'African American Autobiography' are restricted to advanced students who have 'declared' themselves as English majors. Each group could potentially encounter African American literature on broadly defined modules such as 'Great Traditions in American Literature' or 'The Poet in America'. Similar structures and offerings can be found at a wide variety of universities from Princeton to Wake Forest, to the University of Michigan, Yale and UC San Diego. Once my UK students reach their final third year they do have several modules other than mine to choose from that feature African American content, including 'Literature of the Civil Rights Movement' and 'Fiction and Ethnicity.' A key 
difference between the US and UK systems is volume and choice, with the US, to generalise, providing more of both.

"Herman Beavers, 'African American women writers and popular fiction: theorizing black womanhood' Culture' in, ed. Maryemma Graham The Cambridge Companion to the African American Novel (Cambridge University Press, 2006) 264-5.

12 'Why is my Curriculum White?' UCL TV accessed 7 August 2015 https://www.youtube.com/watch?v=Dscx4h2l-Pk

See also, Mariya Hussain, 'Why is my Curriculum White' National Union of Students, 1 March 2015, accessed 30 September 2015 http://www.nus.org.uk/en/news/whyis-my-curriculum-white/

${ }^{13}$ Lee Horsley, $20^{\text {th }}$ Century Crime Fiction, (Oxford: Oxford University Press, 2005) 56.

${ }^{14}$ Ibid., 6.

${ }^{15}$ Helen Carr, 'Introduction: genre and women's writing in the postmodern world' in Helen Carr (ed) From My Guy to Sci-Fi: Genre and Women's Writing in the Postmodern World,' 6.

${ }^{16}$ Beavers, 'African American women writers,' 264.

${ }^{17}$ Ibid., 265.

${ }^{18}$ Stephen F. Soitos, The Blues Detective: A Study of African American Detective Fiction (Amherst: University of Massachusetts Press, 1996) 180.

${ }^{19}$ Dietzel, 'The African American Novel,'159-160.

${ }^{20}$ Soitos succinctly defines signifying as 'an African American language act whose characteristics include irony, indirection, humour, and circumlocution,' The Blues Detective 159. See also, Henry Louis Gates, Jr The Signifying Monkey: A Theory of African-American Literary Theory (USA: Oxford University Press, 1988).

${ }^{21}$ My argument for the inclusion of crime fiction recalls previous interrogations of how canonicity shapes teaching and learning practices for African American literature, as vigorously debated in 'culture wars' of the 1990s, to the contemporary, student-led interrogation of similar issues in UK universities classrooms, epitomised by the Why is My Curriculum White campaign.

${ }^{22}$ Claire Wells 'Writing Black: Crime Fiction's Other', in Klein, Kathleen Gregory (ed.) Diversity and Detective Fiction (Bowling Green: BGSU Popular Press, 1999), 206.

${ }^{23}$ Interview with the author 19 October 2015.

${ }^{24}$ Interview with the author 19 October 2015. 
${ }^{25}$ Dietzel, 'The African American Novel', 158.

${ }^{26}$ Ibid., 156.

${ }^{27}$ William Andrews, review of Incidents in the Life of a Slave Girl. Written by Herself by Harriet A. Jacobs, Jean Fagan Yellin Black American Literature Forum Vol. 21, No. 4 (Winter, 1987), pp. 463-465. Andrews' review gives a concise account of the significance of Yellin's research for the status of Jacobs' narrative within African American and women's literature.

28 Jan Meyer and Ray Land 'Threshold Concepts and Troublesome Knowledge: Linkages to ways of Thinking and Practicing within the Disciplines' Occasional Report 4 (C) ETL Project, Universities of Edinburgh, Coventry and Durham, 2003. Enhancing Teaching-Learning Environments in Undergraduate Courses Project Higher and Community Education School of Education University of Edinburgh Paterson's Land Holyrood Road Edinburgh.

${ }^{29}$ Meyer and Land, 'Threshold Concepts and troublesome Knowledge,' 10.

${ }^{30}$ Ibid., 6.

31 Locke was inspired to write The Cutting Season after attending a wedding at the Oak Alley Plantation in Mississippi (www.oakalley.com). The plantation offers tours throughout the year to the general public and boasts a meticulously restored 'Big House' and 'Slave Quarters'. Perhaps the most famous live re-enactment tourist attraction in the American South is Colonial Williamsburg. Like Oak Alley and the fictional Belle Vie, you can plan to hold your wedding there or visit as a family or a school group. One activity listed on the website is to tour family homes and gardens and, 'See the elegant furnishings and eye-catching wallpapers of the wealthy, the modest dwellings of the "middling sort," and the spartan quarters of the enslaved. Meet the people who live and work inside.' These people are played by actors in period dress. accessed 30 October 2015 http://www.colonialwilliamsburg.com/do/revolutionary-city/tour-the-city.

${ }^{32}$ The "New South' refers to the period after the American Civil War when the southern states both had to rebuild themselves and shift away from an entirely agrarian economy. A later meaning, and the one I am invoking, emerges at the end of the $20^{\text {th }}$ century, led by a resurgent and growing black middle class, one which was both home grown and which migrated in reverse, from the North. In the late $20^{\text {th }}$ century, the 'New' South becomes a destination whereas the Old South had for generations been a place black people had been desperate to leave. Atlanta, after hosting the 1996 Olympics, is seen as a city which epitomises this New South.

33 'Colin Marshall interviews Attica Locke', Los Angles Review of Books, LARB Podcast, 5 March 2014, accessed 18 October 2015, https://lareviewofbooks.org/interview/podcast-54-attica-locke/

${ }^{34}$ lbid. 
35 Deborah L. Madsen 'Teaching Trauma: (Neo-) Slave Narratives and Cultural (Re-) Memory' in, ed. Gina Wisker Teaching African American Women's Writing (London: Palgrave MacMillan, 2010) 60.

${ }^{36}$ See for instance, Traces, Codes, and Clues Reading Race in Crime Fiction by Maureen T. Reddy, Diversity and Detective Fiction, edited by Kathleen Gregory Klein and The Blues Detective: A Study of African American Detective Fiction by Stephen F. Soitos. In addition, several edited collections on crime fiction published in the last fifteen to twenty years include chapters on feminist, 'ethnic', postcolonial or African American crime fiction.

${ }^{37}$ Reddy, Traces, Codes, and Clues, 52.

${ }^{38}$ Soitos, The Blues Detective, 11.

\section{Bibliography}

Beavers, Herman 'African American Woman Writers and Popular Fiction: Theorizing Black Womanhood' in Angelyn Mitchell and Danille K. Taylor (eds) The Cambridge Companion to African American Women's Literature (Cambridge and New York: Cambridge University Press, 2009). 262-277.

Carr, Helen, 'Introduction: genre and women's writing in the postmodern world' in Helen Carr (ed) From My Guy to Sci-Fi: Genre and Women's Writing in the Postmodern World (London: Pandora 1989) 3-14.

Cobb, William Jelani 'The New South's Capital Like to Contradict Itself' The Washington Post July 13 2008, accessed 31 October 2015 http://www.washingtonpost.com/wpdyn/content/article/2008/07/11/AR2008071102393.html

Dietzel, Suzanne B. 'The African American Novel and Popular Culture' in Maryemma Graham (ed.) The Cambridge Companion to the African American Novel (Cambridge University Press, 2006).

Gates Jr, Henry Louis 'The Master's Pieces: On Canon Formation and the African American Tradition' in Loose Canons: Notes on the Culture Wars, (New York: Oxford University Press, 1992) 17-42.

Gates Jr, Henry Louis and Nellie Y. McKay, editors The Norton Anthology of African American Literature Second Edition (W.W. Norton \& Co, 1997, 2004).

Horsley, Lee, Twentieth-Century Crime Fiction (Oxford: Oxford University Press, 2005). 
Hussain, Mariya, 'Why is my Curriculum White' National Union of Students, 1 March 2015, accessed 30 September 2015 http://www.nus.org.uk/en/news/why-is-mycurriculum-white/

Locke, Attica, Black Water Rising. (London: Serpent's Tail, 2009). Pleasantville. (London: Serpent's Tail, 2015).

_ The Cutting Season. (London: Serpent's Tail, 2012).

Kennedy, Liam 'Black Noir: Race and Urban Space...' in Messent, Peter (ed.) Criminal Proceedings: The Contemporary American Crime Novel (London: Pluto Press, 1997). 42-61.

Klein, Kathleen Gregory (ed.) Diversity and Detective Fiction (Bowling Green: BGSU Popular Press, 1999).

Madsen, Deborah L. 'Teaching Trauma: (Neo-) Slave Narratives and Cultural (Re-) Memory' in, ed. Gina Wisker Teaching African American Women's Writing (Basingstoke Palgrave McMillan, 2010) 60-74.

Marshall, Colin, 'Colin Marshall interviews Attica Locke', Los Angles Review of Books LARB Podcast, 5 March 2014, accessed 18 October 2015, https://lareviewofbooks.org/interview/podcast-54-attica-locke/

Miller, Vivian and Helen Oakley (Eds) Cross Cultural Connections in Crime Fiction (Basingstoke: Palgrave McMillan, 2012).

Reddy, Maureen Traces, Codes, and Clues: Reading Race in Crime Fiction. (Rutgers University Press, 2002).

Rowland, Susan, From Agatha Christie to Ruth Rendell: British Women Writers in Detective and Crime Fiction (Basingstoke: Palgrave, 2001).

Schmid, David, 'From the Locked Room to the Globe: Space in Crime Fiction' in Miller, Vivian and Helen Oakley (eds) Cross Cultural Connections in Crime Fiction (Basingstoke: Palgrave McMillan, 2012), 7-23.

Soitos, Stephen F. The Blues Detective: A Study of African American Detective Fiction (Amherst: University of Massachusetts Press, 1996).

Swirksi, Peter. From Lobrow to Nobrow (Montreal: McGill-Queen's University Press, 2005).

UCL TV, 'Why is my Curriculum White?' accessed 7 August 2015 https://www.youtube.com/watch?v=Dscx4h2l-Pk

Wells, Claire 'Writing Black: Crime Fiction's Other' in Klein, Kathleen Gregory (ed.) Diversity and Detective Fiction (Bowling Green: BGSU Popular Press, 1999), 205-223. 